\title{
PRESUPPOSITION IN BEAUTY AND THE BEAST MOVIE SCRIPT
}

\author{
Yossi Kristy, Deliana, Yulianus Harefa \\ Universitas Sumatera Utara, Medan, Indonesia \\ E-mail: yossikristyshn@gmail.com
}

Received: 31 July 2020

Accepted: 14 December 2020

\begin{abstract}
This research was intended to find out the types of presupposition in the character's utterances of Beauty and the Beast movie script and describe the meaning of presupposition that are represented in the movie script. This research used a descriptive qualitative method, which was carried out by collecting, grouping, analyzing and interpreting the research data. The data in this research were the utterances of the characters in movie script containing presupposition. The data were collected through four steps: observation, taking note, data validation and setting them in tables. Based on the data analysis, it was found that 6 types of presupposition were used in the character's utterances of the movie script. The most frequent type of presupposition used by the characters was existential presupposition with 26 data of 58 data found in this movie script. The second type of presupposition often used was factive presupposition with 9 data found in the data. Then, the third was lexical presupposition consisting of 8 data and the fourth was structural presupposition with the same number. The fifth type of presupposition used was non-factive presupposition with 4 data found in this research. The last type of presupposition used in this research was counter-factual presupposition with 3 data found in the movie script.
\end{abstract}

Keywords: movie script, presupposition, existential, factive, lexical, structural.

\section{Introduction}

This research investigated the presupposition in the Beauty and the Beast movie script. This study aimed to find out the types of presupposition and describe the meaning of presupposition that are represented in that movie script. As stated by Yule (1996: 3) pragmatics is a study of speaker's meaning. The definition above implies that in communication between speaker and listener, pragmatics is needed. Moreover, in studying pragmatics, an intended meaning, assumption, purpose, goal and the kind of the actions will be understood. Presupposition is one of the important aspects in pragmatics which examines the speaker's utterance since the speaker commonly communicates more meanings than it is said.

According to Yule (1996: 25), presupposition is something the speaker assumes to be case prior to make an utterance. Based on the definition, presupposition is considered as an assumption that someone has in mind when they want to make an utterance. Moreover, according to Perl (2020), presupposition is a common ground element that is embedded in utterances that are assumed by the writer and reader or speaker and listener.

Yule (1996) divides six types of presupposition. (1) Existential Presupposition: this type of presupposition is assumed to be present in possessive construction and it is not only in that construction but more commonly in any definite phrases. (2) Factive Presupposition 
presupposes information as a fact by using a verb like know. (3) Non-factive Presupposition: this is the one that is assumed not to be true; (4) Lexical Presupposition: in the case of lexical presupposition the speaker's usage of a particular expression is taken to presuppose another (unstated) concept. (5) Structural Presupposition: this type can lead listeners to believe that the information given is necessarily true, rather than just the presupposition of asking question. (6) The last type is Counter-factual Presupposition, in this type the meaning of what is presupposed is not only true, but is the opposite of what is true, or 'contrary to facts'. Here are some utterances found in the movie script containing presupposition:
(a) Monsieur Jean
: Good morning Belle!
(b) Belle
: Good morning, Monsieur Jean! Have you lost something again?

In this utterance, the setting of the time is when Belle and Monsieur Jean meet in a stable. Note that utterance (a) is triggered by the words "again" as the marker of lexical presupposition. This bold utterance was classified as the lexical presupposition because it conveys a meaning that the speaker indicated something lost in the past, which belongs to Monsieur Jean.

In the study of meaning, context cannot be ignored from the sentence or utterance. The presupposition found in sentence is interpreted by considering the context that exists in the situation when an utterance is spoken. The listener needs to consider the context in order to find out the intended meaning of the speaker's information. Context is a significant aspect of understanding the meaning of the utterance. Yule (1996: 21) states that context is a situation accompanying the production of utterance. Therefore, context cannot be separated from understanding the meaning of an utterance. The utterance can be analyzed and interpreted correctly if the listener pays attention to the context. The data of presupposition can be found in media such as talk show, speech, conversation, and movie.

A movie is known as one media that reflects the social life of human being. It is also known as a type of visual communication which uses moving pictures and sound to tell stories. Conversation among the characters becomes the most important aspects in a movie. There are many movies which can be analyzed to find presupposition phenomena such as The Hotel Transylvania, The Conjuring, Facing Giant Movie, Maleficent and many more. Each of them has a genre that is classified as comedy, horror and religious drama and all of which are created to entertain the spectators.

The researchers choose the American movie entitled Beauty and the Beast to find out the presupposition of the conversation among the characters in this movie because this movie has accepted four nominations at the 23rd Critics' Choice Awards. This movie also received Academy Award nominations for Best Production Design and Best Costume Design at the 90th Academy Awards. Moreover, the content of this movie carries good moral values about how to adapt oneself to live with new people and how to keep a good communication with them. As known in this movie the beast and Belle will never get closer if the beast cannot build a good communication with new people. In their conversation, the utterances are used by the characters when they communicate with others. The conversations in the movie consist of various types of presupposition which are adopted as the data of the research because they represent the complex cases of presupposition and various meanings they may convey. 


\section{Literature Review}

According to Yule (1996: 3), pragmatics is a study of contextual meaning. It is concerned with the study of meaning as it is communicated by a speaker or a writer and interpreted by a listener or a reader. It means that the study of pragmatics builds a bridge between the speaker and the listener so that there is no misinterpretation of meaning and the message is conveyed clearly. In addition, Huang (2007: 2) states that one of language studies in pragmatics is studying about an assumption, and that assumption is called presupposition.

A phenomenon of presupposition exists in the middle of a conversation. It means that every utterance produced by the speaker is related to the assumption created by the speaker when the speaker hears the previous utterance. In addition, presupposition is considered as a mechanism used implicitly to make assumption in day to day language. Hudson (2000:321) states that a presupposition is something assumed (presupposed) to be true in a sentence which asserts other information. It will generally remain a necessary assumption whether the utterance is placed in the form of an assertion, denial or question and can be associated with a specific lexical item or grammatical feature in the utterance.

Presupposition refers to assumption implicitly made by speakers and listeners which are necessary for the correct interpretation of utterances. It is something as speaker's assumption to be the case prior for making an utterance. For example, the sentence "My cat was run over yesterday" is assumed for the truth condition of "I have a cat".

Moreover, Yule (1996: 25) argues that presupposition is something the speaker assumes to be case prior to making an utterance. In line with Yule's ideas of presupposition, Levinson (1983: 167) states that presupposition is a pragmatic inference, which means that it is based on the contextual assumption that is underlain by the cooperativeness of participants in a conversation, rather than the linguistic structures of the sentence. In other words, presupposition is the assumption that someone has in mind. It means when someone hears an utterance or reads a sentence he keeps it in his mind.

Saeed (1997) states presuppositions are produced by particular words or construction, together sometimes called presupposition triggers. Therefore, there are presupposition triggers consisting of words, phrases, and structures. According to Grundy (2000), in identifying presupposition there are two ways that can be used. The first way is through presupposition triggers, and the second one is to think of them as ways of expressing shared or non controversial knowledge.

People always use different kinds of utterances while interacting with others, that is why according to Yule (1996: 27) there are six types of presupposition based on the indicators of potential presupposition; they are existential presupposition, factive presupposition, lexical presupposition, structural presupposition, non-factive presupposition, and counter-factual presupposition.

\section{a. Existential Presupposition}

An assumption of the existence of the entities named by the speaker is called existential presupposition. This type of presupposition is not only assumed to be present in possessive construction but more generally in any definite noun phrase.

Example:

Tracy's brother's car. $\quad$ < 'Tracy has a brother >> 
This sentence presupposes that both Tracy and her brother exist. The speaker may also hold the more specific presupposition that she has a brother and her mother has a lot of money because he has a car.

\section{b. Factive Presupposition}

Factive Presupposition is the assumption that something can be treated as a fact/truth by use some verbs such as "know", "realize", "aware", "regret" and "glad". In this presupposition, the speaker makes the hearer or reader trust in his/her utterance and the information of the utterance treats as a fact.

Example:

She didn't realize he was ill. $\quad \quad<$ He was ill $\gg$

In the sentence above, the part of the sentence that can be presupposed is "He was ill" because it is the fact or the part of the sentence that must be true even though she realized it or she did not realize it.

\section{c. Non-factive Presupposition}

Non-factive presupposition is associated with some verbs that are assumed not to be true. People often use the verbs such as 'dream', 'imagine', 'pretend' to presuppose that what follows is not true.

Example:

I dreamed that I was rich. $\quad<<\mid$ was not rich $>>$

In the example above, the use of the verb "dreamed" shown that the clause following the verb "I was rich" is not true. It means that the presupposition is "I was not rich".

\section{d. Lexical Presupposition}

Lexical presupposition is the assumption that speaker uses one form with asserted meaning then it is interpreted conventionally with another (non-asserted) meaning. This presupposition involves the lexical items like "stop", "start", and "again". In this case, a particular expression is used by the speaker to presuppose another (unstated) concept.

Example:

He stopped smoking. $\quad<<$ He used to smoke >>

The use of one verb "stopped" can lead to the presupposition that in the past "he" has a habit to smoke.

\section{e. Structural Presupposition}

Structural Presupposition is the assumption associated with the use of certain words and phrases. In this case, certain sentence structures have been analyzed as conventionally and regularly presupposing that part of the structure is assumed to be true. For example, the wh-question construction in English, as shown example in bottom, is conventionally interpreted with the presupposition that the information after the wh-form (i.e. when and where) is already known to be case.

Where did you buy the bike? $\quad<$ YYou bought the bike>> 
The example above show that the listener perceives that the information presented is necessarily true rather than just the presupposition of the person asking the question. In addition, while asking the question the speaker also presupposes something that is actually part of the question formation itself.

\section{f. Counter-factual Presupposition}

Counter-factual presupposition is the assumption that what is presupposed is not only not true, but is the opposite of what is true, or contrary to facts.

Example:

If you were my friend, you would have helped me >> You are not my friend

The example above presupposes that the information in the if-clause is not true at the time of utterance. In addition, the example presupposes you are not my friend. It is a conditional structure of the type that is generally called counter-factual conditional.

\section{Research Method}

This study is a descriptive qualitative research. According to Creswell (2009: 3), research is a process of steps used to collect and analyze information to increase our understanding of a topic or issue. Moreover, Isaac and Michael (1987: 18) state that the aim of descriptive research is to explain systematically the facts and characteristics of a given population or area of interest, factually and accurately. It means that the data in this research are analyzed by collecting, grouping, analyzing, and interpreting the research data. Descriptive research means that the data in this research are described or explained.

The data of this study are the utterances of the characters in the movie Beauty and the Beast, while the source of data was the movie script of Beauty and the Beast by Bill Condon. As stated by Lofland and Lofland in Moleong (2004: 112), the main data of qualitative research are language and action.

Based on Sutopo's idea (2006: 66), the data are collected through non-interactive method because the researchers are not involved in the interaction; thus, the steps of collecting the data are conducted as follows.

a. Downloading Beauty and the Beast movie transcript from the IMSDb,

b. Watching the movie, trying to understand it thoroughly, finding some important details to support this research and then looking for utterances suitable for the project,

c. Reading and observing utterances in the movie transcript, and

d. Classifying the types of presupposition found in the conversations of Beauty and the Beast movie based on the theory of Yule.

In addition, this research also used referential method and distributional method. The referential method was used to select utterances in the movie script in order to classify the data based on the types of presupposition stated by Yule. Then, the distributional method was used to analyze the data as in the following stages.

1. First, the researchers identified and selected the utterances produced by the characters in Beauty and the Beast movie when they interacted with each other.

2. Second, the researchers classified the utterances based on the types of presupposition stated by Yule (1996: 26-30). 
3. Third, the researchers analyzed and interpreted the presupposition meaning that contains presupposition triggers in the utterance.

4. Finally, the researchers drew conclusions based on the research findings

\section{Results and Discussion}

Presupposition terms are divided into six types, namely existential presupposition, factive presupposition, lexical presupposition, structural presupposition, non-factive presupposition, and counter-factual presupposition. Based on the analysis of data, it is found that the most frequent type of presupposition used by the characters in the movie was existential presupposition which was used 26 times of the total utterances used by the character. Then, factive presupposition was used 9 times, whereas lexical and structural presupposition were used in the same frequency 8 times. Meanwhile, the other two types of presupposition were used less frequently, in which non-factive presupposition was used 4 times and counter-factual presupposition was used 3 times.

The discussions of some utterances containing presupposition triggers found in the movie are as the following.

\section{Data 1}

Pere Robert : Ah, if it isn't the only bookworm in town. So, where did you run off to this week?

Belle : Two cities in Northern Italy. I didn't want to come back! Have you got any new places to go?

The utterances above are classified as the existential presupposition, it is triggered by the words "Northern Italy" as the marker of existential presupposition. This utterance classified as the existential presupposition because it conveys the existence of country named Northern Italy which is conventionally interpreted that Belle has read "Romeo and Juliet" that has the setting in two cities in Northern Italy.

\section{Data 3}

Lefou

: Exactly! Who needs her when you've got us!

Gaston : Yes... But ever since the war, I've felt like I've been missing something. And she's the only girl that gives me that sense of...

The utterances above are classified as existential presupposition which is triggered by the noun phrase "the war". It is considered as existential presupposition because the speaker conveys that the war exists and it is supported by the word but ever since the war. Furthermore, it also implies that Gaston was a war hero at that time as seen from Lefou's words below : GASTON! STOP! Breathe. Think happy thoughts. Go back to the war. Blood, explosions, countless widows.

\section{Data 6}

Gaston : Belle! I heard you had trouble with the Headmaster. He never liked me either. Can I give you a little advice about the villagers though?

Belle : : All I wanted was to teach a child to read.

Gaston : The only children you should concern yourself with...are your own. 
The utterances above are categorized as existential presupposition which is triggered by the words "the Headmaster". It is considered as existential presupposition because the speaker conveys the existence of a school which is led by the headmaster.

\section{Data 22}

Maurice $\quad$ : Goodbye, Belle. Come on, Philippe. You know the way.

The utterance above is classified as the factive presupposition, it is triggered by the word "know" as the marker of factive presupposition. From this utterance, the word "know" is used in the sentence to denote fact that Philippe knows the way.

\section{Data 25}

Lumiere : You must forgive first impressions. I hope you are not too startled.

Belle : Why would I be startled ? I'm talking to a candle

The utterances above are classified as the factive presupposition, it is triggered by the word "hope". From this utterance the words "hope you are not too" is used in the sentence to denote fact that Belle is startled because a candle named Lumiere can talk like a human being.

\section{Data 29}

Belle : He took me there. I know what happened to Mama.

Maurice : Then you know why I had to leave her there. I had to protect you. I've always tried to protect my little girl, probably too much.

The utterances above are classified as the factive presupposition, it is triggered by the word "know" as the marker of factive presupposition. From this utterance the words "know" is used in the sentence to denote fact that Belle knows the cause of her mother's death in the past.

\section{Data 34}

Belle : Papa.

Maurice $\quad$ : Oh, Belle. I thought l'd lost you.

The utterances above are classified as the non-factive presupposition, it is triggered by the word "thought" as the marker of non-factive presupposition. The presupposition used in Maurice's utterance is a non-factive presupposition because it is presupposed that Maurice does not lose his daughter Belle.

\section{Data 37}

Lumiere : : I would risk anything to kiss you again, Plumette.

Plumette : : No, my love. I've been burned by you before. We must be strong.

The utterances above are classified as the lexical presupposition, it is triggered by the word "again" as the marker of lexical presupposition. The presupposition used in Lumiere's utterance is a lexical presupposition because it is presupposed that the speaker Lumiere was kissing Plumette before. 


\section{Data 41}

Beast : You came back.

Belle : : Of course I came back. I'll never leave you again.

The utterances above are classified as the lexical presupposition, it is triggered by the word "again" as the marker of lexical presupposition. The presupposition used in Belle's utterance is a lexical presupposition because it is presupposed that Belle was leaving the Beast before.

\section{Data 42}

Mrs. Potts : Chip! Look at you! You're a little boy again! What did I tell you, darling? You smell so good!

The utterance above is classified as the lexical presupposition, it is triggered by the word "again" as the marker of lexical presupposition. The presupposition used in Mrs Potts's utterance is a lexical presupposition because it is presupposed that Chip was a boy before.

\section{Data 45}

Belle : Papa? Is that you?

Maurice : Belle! How did you find me?

The utterances above are classified as the structural presupposition, it is triggered by the asking question "How did you find me?". The presupposition used in Maurice's utterance is a structural presupposition because it is presupposed that Belle found her father.

\section{Data 49}

Maurice : Warn him? How did you get away from him?

Belle : He let me go, Papa. He sent me back to you

The utterances above are classified as the structural presupposition, it is triggered by the asking question "How did you get away from him?". The presupposition used in Maurice's utterance is a structural presupposition because it is presupposed that Belle got away from the Beast.

\section{Data 52}

Beast

\section{: Well, if you hadn't run away, none of this would have happened.}

The utterance above is classified as the counter-factual presupposition, it is triggered by the words "if you hadn't run away, none of this would have happened." The presupposition used in the Beast's utterance is a counter-factual presupposition because it can be presupposed that Belle runs away. It also means that the real situation is on the contrary with what is spoken.

\section{Conclusion}

After analyzing the types of presupposition in Beauty and the Beast movie script, it is concluded that the most frequent type of presupposition used by the characters in the movie was existential presupposition which was used 26 times of the total utterances. Then, 
factive presupposition was used 9 times, whereas lexical and structural presupposition with same frequency 8 times. Meanwhile, the other two types of presupposition were used less frequently, non-factive presupposition was used 4 times and counter-factual presupposition was used 3 times.

\begin{tabular}{|c|c|c|c|}
\hline \multirow{2}{*}{ No. } & \multirow{2}{*}{ Types of Presupposition } & \multicolumn{2}{|c|}{ Frequency } \\
\hline & & Number & Percentage \\
\hline 1. & Existential presupposition & 26 & $44.82 \%$ \\
\hline 2. & Factive presupposition & 9 & $15.51 \%$ \\
\hline 3. & Non-factive presupposition & 4 & $6.90 \%$ \\
\hline 4. & Lexical presupposition & 8 & $13.80 \%$ \\
\hline 5. & Structural presupposition & 8 & $13.80 \%$ \\
\hline 6. & Counter-factual presupposition & 3 & $5.17 \%$ \\
\hline & Total & 58 & $100 \%$ \\
\hline
\end{tabular}

Existential presupposition was the most frequent type of presupposition used by the characters in the movie, since there were a lot of definite noun phrases including proper names and possessive constructions that appear in the conversation, and those triggers belong to the features of existential presupposition. Further, it is because the speaker or the character wants to tell the listener that the information which become 'a case' does exist and assumes to be true. On the other sides, it is found that counterfactual presupposition is the less dominant type of presupposition as there are only three expressions in the data that contain counter-factual presupposition. In this type of presupposition, the speaker uses counter-factual presupposition as he/she wants to show the condition which is not only untrue but also the opposite of what is true in the truth case.

The meanings of presupposition found in this movie script are about shared-knowledge, either they are general knowledge (information that already known by the character) or certain knowledge (information that only owned by a particular person or group of people).

\section{References}

Creswell, John. (2009). Research design: Qualitative, quantitative, and Mixed Methods Approaches. $3^{\text {th }}$ Edition. London: SAGE Publications. Inc.

Grundy, P. (2000). Doing pragmatics. New York: Oxford University Press.

Huang, Y. (2007). Pragmatics. Oxford: Oxford University Press.

Hudson, G. (2000). Essential introductory linguistics. Michigan: Blackwell Publishers Inc.

Isaac, S. and W. B. Michael. (1987). Handbook in Research and Evaluation for Education and the Behavioral Sciences. San Diego: Edits Publishers.

Levinson, Stephen C. (1983). Pragmatics. New York: Cambridge University Press.

Moleong Lexy J. (2004). Metodologi Penelitian Kualitatif. Bandung: Remaja Rosdakarya.

Perl, C. (2020). Presupposition, Attitudes, and Why They Matter. Australasian Journal of Philosophy, 98. 2, 363-381. doi: https://doi.org/10.1080/00048402.2019.1621911.

Saeed, J. I. (1997). Semantics. Oxford: Blackwell Publishers, Ltd.

Sutopo, H. B. (2002). Metodologi Penelitian Kualitatif: Dasar-dasar dan Terapannya dalam Penelitian. Surakarta: UNS Press.

Yule, G. (1996). Pragmatics. Oxford: Oxford University Press. 